\title{
Personal Hygiene Practices Associated with Preventing Covid-19 in Semarang City
}

\section{Praktik Higiene Perorangan Terkait Pencegahan Covid-19 di Kota Semarang}

\author{
Deby H. Butarbutar ${ }^{1}$, Nurjazuli Nurjazuli*2 ${ }^{2}$ Nikie A. Y. Dewanti ${ }^{3}$ \\ ${ }^{1,2,3}$ Bagian Kesehatan Masyarakat, Universitas Diponegoro, Semarang
}

DOI: $10.24252 /$ al-sihah.v13i2.23349

Received: 26 August 2021 / In Reviewed: 3 December 2021 / Accepted: 26 December 2021 / Available online: 30 December 2021

(C) The Authors 2021. This is an open access article under the CC BY-NC-SA 4.0 license

\begin{abstract}
The healthcare workers and non-healthcare workers who work in public health centers become the high-risk group infected Covid-19. One of the preventions that can be applied is personal hygiene practice. The aim of the study was to analyze factors related to personal hygiene practice in healthcare workers and non-healthcare workers in order to prevent the Covid-19 at Srondol Health Center, Semarang. The study used an analytical observational method with a cross-sectional approach, and the data were analyzed by using a chi-square test. The sample was determined by a total sampling technique with a sample of 48 workers. The study indicated that the majority of respondents who worked in the health sector $(77,1 \%)$, had a good category of personal hygiene practice $54,2 \%$ and possessed a good category of personal hygiene knowledge 60,4\%. There was a significant correlation between knowledge (p-value $<0,05)$, field of work (p-value 0,041), training (p-value $<0,05)$ and personal hygiene practice. In conclusion, factors related to personal hygiene practice on healthcare workers and non-healthcare workers at Srondol Health Center were knowledge, a field of work, and training. Meanwhile, the non-healthcare workers had poor personal hygiene practices so it was necessary to conduct socialization and monitor their personal hygiene by the health center management team.
\end{abstract}

\begin{abstract}
ABSTRAK
Tenaga kesehatan dan non-kesehatan yang bekerja di Puskesmas menjadi kelompok rentan terinfeksi Covid-19. Salah satu upaya pencegahan yang dapat diterapkan adalah praktik personal hygiene. Tujuan penelitian untuk menganalisis faktor-faktor yang berhubungan dengan praktik personal hygiene pada tenaga kesehatan dan non-kesehatan dalam pencegahan Covid-19 di Puskesmas Srondol Kota Semarang. Metode penelitian menggunakan observasional analitik dengan pendekatan cross sectional serta analisis data dengan uji chi square. Sampel ditentukan dengan teknik total sampling dengan sampel 48 pekerja. Penelitian menunjukkan bahwa mayoritas responden bekerja pada bidang kesehatan $(77,1 \%)$, memiliki praktik personal hygiene kategori baik $54,2 \%$ dan memiliki pengetahuan personal hygiene kategori baik $60,4 \%$. Terdapat hubungan yang signifikan antara pengetahuan ( $\mathrm{p}$-value $<0,05$ ), bidang pekerjaan ( $\mathrm{p}$-value 0,041 ) dan pelatihan ( $\mathrm{p}$-value $<0,05$ ) dengan praktik personal hygiene. Kesimpulan, faktor-faktor yang berhubungan dengan praktik personal hygiene pada tenaga kesehatan dan nonkesehatan di Puskesmas Srondol yaitu pengetahuan, bidang pekerjaan, dan pelatihan. Tenaga non-kesehatan memiliki praktik personal hygiene yang kurang baik sehingga diperlukan sosialisasi dan monitoring personal hygiene oleh manajemen puskesmas.
\end{abstract}

\section{GRAPHICAL ABSTRACT}

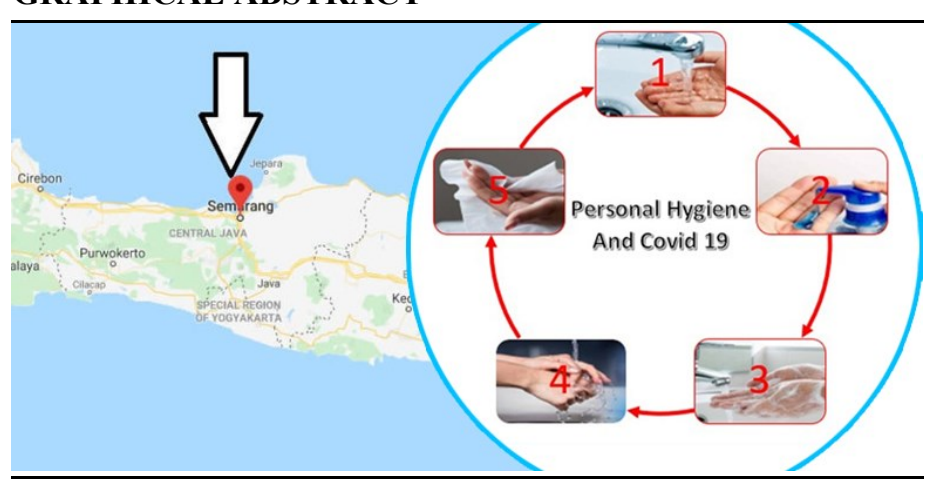

Keyword

covid 19 prevention; healthcare worker; personal hygiene

Kata Kunci:

higiene perorangan; pencegahan covid 19; staf puskesmas

* Correspondence

Ngawen Rt. 03 Rw. 15 Mangunsari, Sidomukti, Salatiga, Jawa Tengah

Email: nurjzl_fkmundip@yahoo.co.id 


\section{PENDAHULUAN}

Covid-19 yang pada mulanya hanya terjadi di Kota Wuhan, kini telah merambat ke seluruh belahan dunia (Dong et al., 2020). Indonesia melaporkan kasus pertama Covid-19 terjadi pada bulan Maret 2020. Kasus pertama terkonfirmasi terjadi pada 2 orang penderita yang memiliki riwayat berhubungan langsung dengan warga negara asing yang terinfeksi Covid-19. Sejak saat itu, dilaporkan adanya peningkatan kasus yang signifikan setiap harinya. Kementerian Kesehatan Indonesia, melaporkan total kasus mencapai 7000 kasus perharinya. (Kementerian Kesehatan Republik Indonesia, 2020) Tingginya kasus infeksi yang terjadi, diikuti dengan tingginya tingkat kematian. Indonesia pernah menduduki posisi case fatality rate (CFR) tertinggi di Asia dengan rata - rata $8-9 \%$ (Johns Hopkins Coronavirus Resource Center , 2021).

Sejak dilaporkannya kasus pertama di Indonesia, pandemi Covid-19 kini telah memenuhi kapasitas rumah sakit dan seluruh sumber daya pelayanan kesehatan (Djalante et al., 2020). Penularan nosokomial pun muncul sebagai pusat permasalahan kesehatan yang perlu diperhatikan (Sahiledengle et al., 2018). Mengingat fasilitas pelayanan kesehatan sering kali menjadi titik penularan infeksi penyakit menular, menjadikan petugas kesehatan sebagai kelompok rentan terhadap infeksi Covid-19 (Mhango et al., 2020; Iversen et al., 2020; Neto et al., 2020). Tingkat infeksi pada petugas kesehatan dilaporkan antara 3 $17 \%$ tergantung pada riwayat, tingkat paparan dan gejala yang timbul (Lan et al., 2020a; Mhango et al., 2020). Lan et al. (2020b), menyatakan dari lima kelompok pekerjaan, petugas kesehatan menjadi kelompok dengan total kasus positif Covid-19 terbanyak di enam negara Asia. Di Indonesia sendiri terdapat 884 jiwa tenaga kesehatan yang gugur akibat dari infeksi Covid-19.

Tenaga non-kesehatan pada fasilitas pelayanan kesehatan ikut menjadi kelompok berisiko terinfeksi Covid-19. Hal ini dikarenakan peran dan beban risiko pekerjaan tenaga non-kesehatan yang bekerja di lingkungan berisiko tinggi akan penularan Covid-19. Alajmi et al. (2020) menyatakan sebanyak $223(33,2 \%)$ responden di bidang non-kesehatan terinfeksi Covid-19. Dilaporkan, tenaga non-kesehatan yang bekerja di fasilitas umum rumah sakit tidak difasilitasi APD (alat pelindung diri) yang sesuai dengan standar kesehatan, pengetahuan dan praktik yang buruk terkait tindakan pencegahan penularan Covid-19.

Kota Semarang menjadi kota dengan kasus tertinggi di Jawa Tengah. Pada April 2021, persentase kontribusi mencapai $10,58 \%$ dari total keseluruhan kasus di Jawa Tengah. Kecamatan Banyumanik merupakan satu dari kecamatan yang ada di Kota Semarang dengan kasus Covid-19 yang cukup tinggi. Kecamatan Banyumanik memiliki 4 puskesmas sebagai fasilitas pelayanan kesehatan meliputi Puskesmas Srondol, Puskesmas Padangsari, Puskesmas Pudakpayung dan Puskemas Ngesrep. Hingga Mei 2021, dari keempat fasilitas pelayanan kesehatan tersebut, Puskesmas Srondol memiliki kasus infeksi Covid-19 terbanyak yaitu 48 pekerja ditemukan 4 petugas kesehatan yang pernah terinfeksi 
Covid-19. Berdasarkan hasil observasi, ditemukan tenaga kesehatan dan nonkesehatan yang tidak membersihkan tangan terlebih dahulu sebelum menyentuh area mata, hidung dan mulut serta tidak menjaga jarak minimal 1 meter antar tenaga kesehatan dan non-kesehatan.

Sebagai lingkungan berisiko tinggi terinfeksi Covid-19, penerapan pengendalian dan pencegahan infeksi menjadi fokus utama setiap tenaga kesehatan dan nonkesehatan (Choi et al., 2021). Hal tersebut telah tercantum dalam Keputusan Menteri Kesehatan Republik Indonesia Nomor 413 Tahun 2020 dimana setiap petugas kesehatan dan non-kesehatan harus mematuhi kewaspadaan standar selama pandemi Covid-19. Kewaspadaan standar tersebut meliputi kebersihan tangan (hand hygiene), penggunaan alat pelindung diri, kebersihan pernafasan, kebersihan lingkungan, penanganan linen, tatalaksana limbah, desinfeksi peralatan perawatan pasien berdasarkan jenisnya. Dalam kewaspadaan standar tersebut terdapat praktik personal hygiene sebagai tindakan pencegahan Covid-19 yaitu kebersihan tangan meliputi 5 momen cuci tangan dan 2 momen tambahan, 6 langkah cuci tangan, durasi membersihkan tangan menggunakan sabun dan hand sanitizer. Kemudian kebersihan pernafasan meliputi penerapan etika batuk dan bersin, penggunaan masker sebagai alat pelindung diri (Menteri Kesehatan Republik Indonesia, 2020).

Kejadian infeksi Covid-19 pada petugas kesehatan di Puskesmas Srondol diindikasikan karena ketidakpatuhan petugas kesehatan akan praktik personal hy- giene. Beberapa penelitian internasional maupun nasional menginformasikan kejadian Covid 19 dikarenakan kepatuhan maupun intensitas paparan yang tinggi dengan pasien yang ditangani petugas, sehingga probabilitas tertular semakin besar. Menurut L. Green dalam menerapkan praktik personal hygiene, terdapat beberapa faktor yang mempengaruhi (Notoatmodjo, 2012). Faktor pertama, faktor predisposisi meliputi jenis kelamin, usia, pengetahuan, tingkat pendidikan dan bidang pekerjaan. Faktor kedua, faktor penguat meliputi dukungan pemerintah berupa pedoman dan pelatihan. Faktor ketiga, faktor pemungkin meliputi ketersediaan fasilitas kebersihan seperti sabun cuci tangan, air bersih, hand sanitizer dan masker. Oleh karena itu penting sekali untuk memastikan bagaimana upaya pencegahan yang dilakukan petugas puskesmas, terutama dalam menerapkan personal hygiene yang merupakan salah satu unsur protokol kesehatan. Dengan demikian, tujuan penelitian ini dilakukan untuk melakukan analisis faktor - faktor yang berhubungan dengan praktik personal hygiene dalam pencegahan Covid-19 di Puskesmas Srondol Kota Semarang.

\section{METODE PENELITIAN}

Penelitian ini merupakan penelitian kuantitatif yang menggunakan metode observasional analitik dengan desain cross sectional. Populasi terdiri dari 37 tenaga kesehatan dan 11 non-kesehatan di Puskesmas Srondol Kota Semarang. Sampel dalam penelitian ini adalah seluruh staf yang ada di Puskesmas Srondol sebanyak 48 pekerja. Variabel bebas meliputi penge- 
Tabel 1

Karakteristik Responden

\begin{tabular}{|c|c|c|}
\hline Karakteristik & frekuensi & $\%$ \\
\hline \multicolumn{3}{|l|}{ Jenis Kelamin } \\
\hline Perempuan & 41 & 85,4 \\
\hline Laki - Laki & 7 & 14,5 \\
\hline \multicolumn{3}{|l|}{ Usia } \\
\hline $20-29$ & 8 & 16,7 \\
\hline $30-39$ & 16 & 33,3 \\
\hline $40-49$ & 10 & 20,8 \\
\hline$\geq 50$ & 14 & 29,2 \\
\hline
\end{tabular}

tahuan, tingkat pendidikan, bidang pekerjaan dan pelatihan. Sedangkan variabel terikat meliputi praktik personal hygiene dalam pencegahan Covid-19. Instrumen penelitian menggunakan kuesioner yang dijawab secara mandiri oleh responden. Kuesioner terdiri dari beberapa butir pertanyaan meliputi 10 butir pertanyaan terkait pengetahuan, 8 butir pertanyaan terkait sikap, dan 11 butir pertanyaan terkait praktik personal hygiene. Pada pengetahuan dan praktik personal hygiene jawaban benar (skor 1) dan salah (skor 0). Pada penelitian ini data tidak berdistribusi normal sehingga cut-off point pengkategorian didasarkan nilai median/ tengah. Data hasil penelitian dianalisis dengan uji statistik chi-square dengan tingkat kesalahan $(\alpha) 0,05$.

\section{HASIL PENELITIAN}

Penelitian ini mengambil sebanyak 48 responden dan diperoleh karakteristik responden seperti dipaparkan pada tabel 1 . Tabel 1 menunjukkan mayoritas responden pada penelitian ini memiliki jenis kelamin perempuan $(85,4 \%)$. Sebagian besar usia responden didominasi pada kategori 30-39 tahun $(33,3 \%)$.
Tabel 2 menunjukkan bahwa sebagian besar responden telah menempuh pendidikan terakhir pada pendidikan tinggi $79,2 \%$. Bidang pekerjaan didominasi oleh tenaga kesehatan dengan persentase $77,1 \%$. Berdasarkan pelatihan yang pernah diikuti, sebanyak $60,4 \%$ responden pernah mengikuti pelatihan terkait tindakan pencegahan Covid-19. Sebagian besar responden memiliki pengetahuan yang baik dengan persentase $60,4 \%$.

Pada praktik personal hygiene, dapat diketahui sebanyak 54,2\% responden telah menerapkan praktik personal hygiene yang baik dalam upaya pencegahan Covid-19 di Puskesmas Srondol. Hasil distribusi frekuensi, ditemukan sebesar $45,8 \%$ responden masuk kedalam kategori kurang baik dalam praktik personal hygiene. Hal ini didukung dengan hasil observasi yang menunjukkan bahwa responden sering menutup mulut menggunakan telapak tangan pada saat batuk. Ditemukan juga responden akan menyentuh area hidung tanpa membersihkan tangan terlebih dahulu menggunakan hand sanitizer.

Tabel 3 menunjukkan hasil analisis bivariat terdapat 3 variabel yang memiliki 
Tabel 2

Distribusi Frekuensi Variabel

\begin{tabular}{lcc}
\hline \multicolumn{1}{c}{ Variabel } & \multicolumn{2}{c}{ Jumlah } \\
\cline { 2 - 3 } & $\mathrm{f}$ & $\%$ \\
\hline Tingkat pendidikan & & 20,8 \\
$\quad$ Pendidikan Dasar - Menengah & 10 & 79,2 \\
$\quad$ Pendidikan Tinggi & 38 & 77,1 \\
Bidang Pekerjaan & & 22,9 \\
$\quad$ Tenaga Kesehatan & 37 & \\
$\quad$ Tenaga Non-Kesehatan & 11 & 60,4 \\
Pelatihan & & 39,6 \\
$\quad$ Pernah & 29 & 60,4 \\
$\quad$ Tidak Pernah & 19 & 39,6 \\
Pengetahuan & & 54,2 \\
$\quad$ Baik & 29 & 45,8 \\
$\quad$ Kurang baik & 19 & \\
Praktik Personal Hygiene & & \\
$\quad$ Baik & 26 & \\
$\quad$ Kurang Baik & 22 & \\
\hline
\end{tabular}

hubungan signifikan dengan variabel terikat yaitu praktik personal hygiene meliputi variabel pengetahuan ( $p$-value $=0,0001)$, bidang pekerjaan $(p$-value $=0,041)$ dan pelatihan terkait praktik personal hygiene $(\mathrm{p}$-value $=0,0001)$.

\section{PEMBAHASAN}

\section{Hubungan Tingkat Pendidikan dengan} Praktik Personal Hygiene

Pada penelitian ini menemukan bahwa respondengan dengan tingkat Pendidikan tinggi memiliki kecenderungan melakukan praktik personal hygiene yang baik namun tidak terdapat hubungan yang signifikan antara tingkat pendidikan dengan praktik personal hygiene. Ditemukan bahwa responden dengan tingkat pendidikan tinggi memiliki praktik personal hygiene yang baik dikarenakan semakin tinggi pendidikan maka semakin tinggi pula ilmu pengetahuan dan informasi yang diperoleh (Notoatmodjo, 2012). Penelitian ini sejalan dengan penelitian
Kim \& Kim, (2020) yang menunjukkan bahwa tidak ditemukannya hubungan antara tingkat pendidikan dengan penerapan tindakan pencegahan Covid-19 pada masyarakat Korea Selatan.

Pada penelitian ini responden dengan pendidikan menengah bekerja sebagai administrasi, petugas kebersihan, pengemudi dan petugas keamanan. Pekerjaan yang dilakukan oleh ketiga responden tersebut tidak berhubungan langsung dengan pasien maupun suspek Covid 19, sehingga responden dengan pendidikan menengah merasa bahwa mereka tidak berisiko tinggi terhadap infeksi Covid-19. Kenapa terjadi demikian karena keterbatasan pengetahuan yang dilatarbelakangi pendidikan yang dimiliki, yaitu pendidikan dasar/menengah yang memang sudah sesuai dengan kriteria saat penerimaan pegawai. Sehingga tingkat pemahaman mereka kurang maksimal yang berdampak pada praktik personal hygiene yang kurang. Mereka tetap melakukan tindakan personal 
Tabel 3

Hubungan antara Variabel Bebas dengan Praktik Personal Hygiene

\begin{tabular}{|c|c|c|c|c|c|c|}
\hline \multirow{3}{*}{ Variabel } & \multicolumn{4}{|c|}{ Praktik Personal hygiene } & \multirow{3}{*}{ Total } & \multirow{3}{*}{ Nilai $\mathrm{p}$} \\
\hline & \multicolumn{2}{|c|}{ Kurang Baik } & \multicolumn{2}{|c|}{ Baik } & & \\
\hline & $\mathrm{n}$ & $\%$ & $\mathrm{n}$ & $\%$ & & \\
\hline \multicolumn{7}{|l|}{ Tingkat Pendidikan } \\
\hline Pendidikan dasar dan menengah & 7 & 70 & 3 & 30 & 10 & 0,152 \\
\hline Perguruan tinggi & 15 & 39,4 & 23 & 60,6 & 38 & \\
\hline \multicolumn{7}{|l|}{ Bidang Pekerjaan } \\
\hline Non-kesehatan & 8 & 72,7 & 3 & 27,3 & 11 & 0,041 \\
\hline Kesehatan & 14 & 37,8 & 23 & 62,2 & 37 & \\
\hline \multicolumn{7}{|l|}{ Pelatihan } \\
\hline Tidak Pernah & 16 & 84,2 & 3 & 15,8 & 19 & 0,0001 \\
\hline Pernah & 6 & 20,7 & 23 & 79,3 & 29 & \\
\hline \multicolumn{7}{|l|}{ Pengetahuan } \\
\hline Kurang Baik & 16 & 84,2 & 3 & 15,8 & 19 & 0,0001 \\
\hline Baik & 6 & 20,7 & 23 & 79,3 & 29 & \\
\hline
\end{tabular}

hygiene dalam melakukan tugas sehari-hari karena memang ada SOP yang sudah disosialisasikan kepada seluruh karyawan yang bekerja di Puskesmas. Sebaliknya masih ada pula petugas puskesmas yang berpendidikan tinggi melakukan praktik personal hygiene yang kurang baik. Hal ini disebabkan karena kesempatan yang terbatas dikarenakan beban/load pekerjaan yang tinggi ataupun sifat lalai di saat-saat kesibukan yang harus tetap dijalankan dan diselesaikan. Namun apabila bicara soal risiko, semua orang baik responden dengan pendidikan tinggi ataupun menengah memiliki risiko terinfeksi yang sama dikarenakan lingkungan pekerjaan sehari-hari yang berisiko tinggi akan terjadinya penularan Covid-19 baik melalui droplet penderita ataupun dengan menyentuh benda yang telah terkontaminasi virus (Mesgarpour et al., 2021; Zhang et al., 2021). Pada dasarnya bahwa semua karyawan yang bekerja di Puskesmas harus melakukan personal hygiene (salah satunya cuci tangan rutin) dan pihak Puskesmas sudah menyediakan fasilitas untuk tindakan tersebut. Penting untuk diperhatikan adalah bagaimana pimpinan puskesmas bisa melakukan pengawasan semaksimal mungkin agar semua karyawan melakukan tindakan personal hygiene dalam rangka meminimalisir risiko penularan Covid 19.

\section{Hubungan Bidang Pekerjaan dengan Praktik Personal Hygiene}

Pada penelitian ini, bidang pekerjaan kesehatan terdiri dari dua yaitu tenaga kesehatan kontak dengan pasien (dokter umum, dokter gigi, perawat, bidan) dan tenaga kesehatan tidak kontak dengan pasien (farmasi, nutrisionis, laborat, sanitarian, epidemiolog dan promosi kesehatan). Sedangkan bidang pekerjaan non-kesehatan meliputi administrasi, akuntan, petugas kebersihan, pengemudi dan petugas keamanan. Hasil analisis, mayoritas responden yang bekerja pada bidang kesehatan memiliki praktik personal hygiene yang baik $(62,2 \%)$ dan responden yang bekerja pada bidang non-kesehatan memiliki praktik personal hygiene yang baik $(27,3 \%)$. Dapat diartikan bahwa, responden dengan bidang 
pekerjaan non-kesehatan cenderung untuk tidak menerapkan praktik personal hygiene. Tenaga puskesmas dengan latar belakang non Kesehatan mempunyai kewajiban menerapkan protokol kesehatan dalam melaksanakan tugas sehari-hari. Hal ini dikarenakan mereka mendapat tugas untuk membantu tenaga Kesehatan yang menangani pasien/suspek Covid 19. Sehingga mau tidak mau harus melakukan Tindakan personal hygiene dengan mencuci tangan dengan sabun secara rutin. Sebaliknya, tidak sedikit $(37,8 \%)$ tenaga kesehatan yang mempunyai tugas langsung menangani pasien/suspek Covid 19 melakukan praktik personal hygiene kurang baik. Hal ini terjadi karena mereka merasa sudah sangat aman dengan mengenakan pakaian hazmat secara lengkap termasuk handscone. Mereka hanya melakukan tindakan personal hygiene di awal mulai kegiatan, selanjutnya bekerja dengan protokol Kesehatan yang sudah ketat.

Adanya perbedaan praktik personal hygiene dapat dikarenakan adanya perbedaan kesadaran tenaga kesehatan dan nonkesehatan. Penelitian Jemal et al., (2020) menyatakan bahwa responden yang bekerja dibidang kesehatan memiliki tingkat perilaku tindakan pencegahan yang baik dikarenakan kesadaran akan pekerjaan yang memiliki risiko tinggi terhadap paparan virus. Tenaga kesehatan seperti perawat, bidan dan analis laborat mengalami peningkatan sebanyak $2 \%, 4 \%$ dan $5 \%$ terhadap praktik pencegahan dan pengendalian dikarenakan kesadaran akan pekerjaan yang lebih rentan terinfeksi.
Peningkatan kesadaran perlu dilakukan untuk meningkatkan praktik personal hygiene yaitu dengan cara monitoring. Monitoring memiliki keunggulan dapat memastikan setiap tenaga kesehatan dan non-kesehatan selalu menerapkan praktik personal hygiene (Adams et al., 2021). Berdasarkan penelitian Waleleng et al., (2020) dengan melakukan monitoring mampu meningkatkan kesadaran tenaga kesehatan dan non-kesehatan terhadap upaya pencegahan Covid-19. Dalam hal ini, monitoring harian dilakukan melalui pengisian formulir praktik personal hygiene (mencuci tangan, penggunaan alat pelindung diri yang lengkap, menjaga jarak minimal 1 meter) yang diisi baik sebelum dan sesudah bekerja serta dilakukan pengawasan berkala secara langsung oleh kepala puskesmas. Hal ini sesuai dengan kondisi puskesmas yang belum memiliki sistem monitoring terhadap kepatuhan tenaga kesehatan dan non-kesehatan terkait praktik personal hygiene.

\section{Hubungan Pelatihan dengan Praktik Personal Hygiene}

Pelatihan yang dimaksud pada penelitian ini adalah kegiatan yang dapat membantu responden memperoleh pengetahuan dan keterampilan dalam menanggapi Covid-19 yaitu tindakan pencegahan dan pengendalian infeksi Covid-19. Jenis pelatihan praktik personal hygiene yang dimaksud berupa pelatihan hand hygiene, etika batuk, penggunaan dan pelepasan APD, desinfeksi lingkungan, penerapan protokol kesehatan seperti pembatasan jumlah pasien dan penandaan jaga jarak 
minimal 1 meter. Pada penelitian ini, sebanyak $60,4 \%$ responden pernah mengikuti pelatihan dan 39,6\% responden tidak pernah mengikuti pelatihan. Ditemukan, responden yang pernah mengikuti pelatihan hand hygiene, etika batuk dan penggunaan serta pelepasan APD berpengaruh terhadap praktik personal hygiene yang baik (79,3\%). Sejalan dengan penelitian Jemal et al. (2020) dimana responden yang pernah mengikuti pelatihan akan dua kali lebih mungkin untuk mempraktikkan tindakan pencegahan. Hal ini dikarenakan dengan memberikan pelatihan dapat mengurangi kesenjangan keterampilan dan pengetahuan terkait praktik personal hygiene diantara tenaga kesehatan dan non-kesehatan. Namun demikian masih terdapat $20,7 \%$ responden yang sudah pernah mendapat pelatihan tapi masih melakukan praktik personal hygiene yang kurang baik karena beban yang tinggi dan dalam kondisi mengenakan pakaian hazmat lengkap. Beban kerja yang sangat tinggi saat pandemic Covid 19 inilah yang membuat mereka kurang melakukan tindakan personal hygiene yang intens meskipun telah memperoleh pelatihan. Pelatihan telah membuat tenaga kesehatan memahami tindakan personal hygiene yang mereka lakukan, namun kesempatan waktu membuat mereka lupa bahkan abai untuk melakukan tindakan personal hygiene.

Pada penelitian ini ditemukan, sebanyak $84,2 \%$ responden yang tidak pernah mengikuti pelatihan memiliki praktik personal hygiene yang buruk. Sehingga dapat diartikan bahwa responden yang tidak mengikuti pelatihan cenderung untuk tidak memperhatikan personal hygiene selama berada di lingkungan puskesmas. Namun dalam penelitian ini ditemukan $15,8 \%$ tenaga puskesmas yang tidak pernah memperoleh pelatihan tetapi melakukan praktik personal hygiene dengan baik. Hal ini bisa terjadi karena ada pembinaan dari pimpinan dan adanya SOP yang harus dijalankan oleh karyawan yang ada di puskesmas. Oleh sebab itu, diperlukan adanya pemerataan pemberian pelatihan kepada mereka yang belum pernah memperolehnya terkait hand hygiene, etika batuk dan penggunaan serta pelepasan APD kepada responden yang tidak pernah mengikuti pelatihan. Terselenggaranya pelatihan dipengaruhi oleh faktor manajemen puskesmas. Dalam hal ini puskesmas membantu meningkatkan kualitas pengetahuan dan kemampuan tenaga kesehatan dan non-kesehatan dalam menerapkan praktik personal hygiene. Dimana dengan adanya pemerataan pelatihan terkait hand hygiene, etika batuk dan penggunaan serta pelepasan APD, maka seluruh tenaga kesehatan dan non-kesehatan dapat berkontribusi dalam menurunkan resiko terjadinya penularan Covid-19 di lingkungan fasilitas pelayanan kesehatan (Storr et al., 2017).

\section{Hubungan Pengetahuan dengan Praktik Personal Hygiene}

Semakin tinggi tingkat pengetahuan seseorang maka akan mempengaruhi sikap, persepsi dan motivasi seseorang dalam menerapkan perilaku sehat (Notoatmodjo, 2012). Hasil penelitian menunjukkan sebanyak $60,4 \%$ responden memiliki pengetahuan baik dan 79,3\% telah menerapkan 
praktik personal hygiene yang baik pula. Ditemukan juga 39,6\% responden memiliki pengetahuan kurang baik memiliki praktik personal hygiene yang kurang baik sebesar $84,2 \%$. Adanya perbedaan pengetahuan didukung dengan keterlibatan responden dalam mengikuti pelatihan terkait praktik personal hygiene. Dimana responden dengan pengetahuan baik dan telah mengikuti pelatihan telah menerapkan praktik personal hygiene yang baik. Berdasarkan penelitian Papagiannis et al. (2020) sebanyak $88,3 \%$ petugas kesehatan di Yunani memiliki pengetahuan yang baik telah berkontribusi besar terhadap keterampilan dalam melakukan pengendalian dan pengelolaan pandemi di Yunani. Dalam penelitian ini terdapat $15,3 \%$ responden yang pengetahuannya kurang baik namun melakukan praktik personal hygiene dengan baik. Mereka melakukan praktik personal hygiene dengan baik karena adanya fasilitas yang disertai SOP yang harus ditaati oleh para karyawan yang bekerja di puskesmas selama pancemi Covid 19. Pembinaan langsung berupa praktik cuci tangan secara bersama-sama dengan karyawan lain membuat mereka sadar harus melakukan praktik personal hygiene secara rutin bersama-sama teman yang lainnya.

Peningkatan pengetahuan tentang praktik personal hygiene yang dapat dilakukan selain dengan mengikuti pelatihan adalah dengan pengadaan sosialisasi (Lai et al., 2020; Eyram et al., 2021). Dalam hal ini sosialisasi memiliki keunggulan dapat dilakukan dalam bentuk video ataupun media cetak (Farooq et al., 2021). Hasil observasi menunjukkan bahwa puskesmas telah melakukan sosialisasi terkait praktik personal hygiene dalam bentuk poster. Namun, poster tersebut hanya ditemukan pada beberapa ruangan di puskesmas dan kurang efektif dalam meningkatkan pengetahuan responden. Optimalisasi sosialisasi yang dapat dilakukan adalah dengan memberikan video edukasi secara berkala dimana video tersebut dikemas secara singkat dan jelas. Sosialisasi tersebut tidak hanya berfungsi untuk menambah pengetahuan tetapi juga berfungsi sebagai pengingat kepada responden untuk tetap menerapkan praktik personal hygiene sebagai bentuk pencegahan Covid-19. Berdasarkan penelitian Jemal et al. (2020) pengadaan sosialisasi sangat efektif dalam meningkatkan pengetahuan tenaga kesehatan dan non -kesehatan akan tindakan pencegahan penularan Covid-19.

\section{KESIMPULAN}

Penelitian ini menyimpulkan bahwa $54,2 \%$ responden telah menerapkan praktik personal hygiene yang baik. Faktor faktor yang memiliki hubungan signifikan dengan praktik personal hygiene dalam pencegahan Covid-19 di Puskesmas Srondol adalah pengetahuan yang baik, bidang pekerjaan kesehatan dan pernah mengikuti pelatihan. Tenaga non-kesehatan memiliki praktik personal hygiene yang kurang baik seperti menutup mulut menggunakan telapak tangan apabila hendak batuk dan menyentuh area mata tanpa membersihkan tangan terlebih dahulu, sehingga diperlukan sosialisasi dan monitoring personal hygiene oleh manajemen puskesmas. 


\section{DAFTAR PUSTAKA}

Adams, V., Song, J., Shang, J., McDonald, M., Dowding, D., Ojo, M., \& Russell, D. (2021). Infection prevention and control practices in the home environment: Examining enablers and barriers to adherence among home health care nurses. American journal of infection control, 49(6), 721-726. https:// doi.org/10.1016/j.ajic.2020.10.021

Alajmi, J., Jeremijenko, A. M., Abraham, J. C., Alishaq, M., Concepcion, E. G., Ajwad Butt, A., \& Abou-Samra, A.-B. (2020). Covid-19 Infection Among Healthcare Workers in A National Healthcare System: The Qatar Experience. Journal of Infection Disease, 100, 386-389. https:// doi.org/10.1016/j.ijid.2020.09.027

Choi, U. Y., Kwon, Y. M., Kang, H. J., Song, J. H., Lee, H. Y., Kim, M. S., Kahm, S. H., Kwon, J. Y., Kim, S. H., Lee, S.-H., Choi, J. H., \& Lee, J. (2021). Surveillance Of The Infection Prevention And Control Practices Of Healthcare Workers By An Infection Control Surveillance-Working Group and A Team Of Infection Control Coordinators During The Covid-19 Pandemic. Journal of Infection and Public Health. https:// doi.org/10.1016/j.jiph.2021.01.012

Djalante, R., Lassa, J., Setiamarga, D., Sudjatma, A., Indrawan, M., Haryanto, B., \& Warsilah, H. (2020). Review and analysis of current responses to COVID-19 in Indonesia: Period of January to March 2020. Progress in Disaster Science, 6, 100091. https:// doi.org/10.1016/j.pdisas.2020.100091

Dong, E., Du, H., \& Gardner, L. (2020). An interactive web-based dashboard to track Covid-19 in real time. The Lancet Infectious Diseases, 20(5), 533-534. https://doi.org/10.1016/ S1473-3099(20)30120-1

Eyram, M., Id, A., Dajaan, S., Id, D., Duti, V., Id, E. A., Ashinyo, A., Asare, B. A., Ackon, A. A., Akoriyea, K., \& Kuma-aboagye, P. (2021). Infection prevention and control compliance among exposed healthcare workers in Covid -19 treatment centers in Ghana: A descriptive cross-sectional study. 1-13. https:// doi.org/10.1371/journal.pone.0248282

Farooq, A., Laato, S., Islam, A. N., \& Isoaho, J. (2021). Understanding the impact of information sources on COVID-19 related pre- ventive measures in Finland. Technology in Society, 65, 101573. https://doi.org/10.1016/ j.techsoc.2021.101573

Iversen, K., Bundgaard, H., Hasselbalch, R. B., Kristensen, J. H., Nielsen, P. B., Pries-Heje, M. Knudsen, A. D., Christensen, C. E., Fogh, K., Norsk, J. B., Andersen, O., Fischer, T K., Jensen, C. A. J., Larsen, M., TorpPedersen, C., Rungby, J., Ditlev, S. B., Hageman, I., Møgelvang, R., ... Ullum, H. (2020). Risk of Covid-19 in health-care workers in Denmark: an observational cohort study. The Lancet Infectious Diseases, 20(12), 1401-1408. https://doi.org/10.1016/ S1473-3099(20)30589-2

Jemal, K., Gashaw, K., Kinati, T., Bedada, W., \& Getahun, B. (2020). Clean and Safe Healthcare Environment: Knowledge, Attitude , and Practice of Infection Prevention and Control among Health Workforce at North Showa Zone Oromiya Region. Journal of Environmental and Public Health, 2020. https://doi.org/10.1155/2020/6021870

Johns Hopkins Coronavirus Resource Center (2021). Covid-19 Map. Available online: https:// coronavirus.jhu.edu/map.html

Kementerian Kesehatan Republik Indonesia (2020) Data Covid-19 Indonesia. Available online: https://www.kemkes.go.id/

Kim, S., \& Kim, S. (2020). Analysis of the Impact of Health Beliefs and Resource Factors on Preventive Behaviors against the Covid-19 Pandemic. International Journal of Environmental Research and Public Health, 17(22), 1-21. https://doi.org/10.3390/ ijerph17228666

Lai, X., Wang, X., Yang, Q., Xu, X., Tang, Y., Liu, C., Tan, L., Lai, R., Wang, H., Zhang, X., Zhou, Q., \& Chen, H. (2020). Will Healthcare Workers Improve Infection Prevention And Control Behaviors As Covid-19 Risk Emerges And Increases, In China? Journal of Antimicrobial Resistance and Infection Control, 9(1). https:// doi.org/10.1186/s13756-020-00746-1

Lan, F.Y., Filler, R., Mathew, S., Buley, J., Iliaki, E., Bruno-Murtha, L. A., Osgood, R., Christophi, C. A., Fernandez-Montero, A., \& Kales, S. N. (2020a). Covid-19 symptoms predictive of healthcare workers' SARS-CoV-2 PCR results. PLOS ONE, 15(6), e0235460. https://doi.org/10.1371/ 
journal.pone. 0235460

Lan, F. Y., Wei, C. F., Hsu, Y. T., Christiani, D. C., \& Kales, S. N. (2020b). Work-Related Covid-19 Transmission In Six Asian Countries/Areas: A follow-Up Study. PLoS ONE, 15(5), 1-11. https://doi.org/10.1371/ journal.pone. 0233588

Menteri Kesehatan Republik Indonesia. (2020). Keputusan Menteri Kesehatan Republik Indonesia Nomor HK.01.07/ MenKes/413/2020 Tentang Pedoman Pencegahan dan Pengendalian Corona Virus Disease 2019 (Covid-19).

Mesgarpour, M., Abad, J. M. N., Alizadeh, R., Wongwises, S., Doranehgard, M. H., Ghaderi, S., \& Karimi, N. (2021). Prediction of the spread of Corona-virus carrying droplets in a bus-A computational based artificial intelligence approach. Journal of Hazardous Materials, 413, 125358. https:// doi.org/10.1016/j.jhazmat.2021.125358

Mhango, M., Dzobo, M., Chitungo, I., \& Dzinamarira, T. (2020). Covid-19 Risk Factors Among Health Workers: A Rapid Review. Journal of Safety and Health at Work, 11 (3), 262-265. https://doi.org/10.1016/ j.shaw.2020.06.001

Mhango, M., Dzobo, M., Chitungo, I., \& Dzinamarira, T. (2020). COVID-19 risk factors among health workers: a rapid review. Safety and health at work, 11(3), 262265. j.shaw.2020.06.001

https://doi.org/10.1016/

Neto, M. L. R., Almeida, H. G., Esmeraldo, J. D. A., Nobre, C. B., Pinheiro, W. R., de Oliveira, C. R. T., \& da Silva, C. G. L. (2020). When health professionals look death in the eye: the mental health of professionals who deal daily with the 2019 coronavirus outbreak. Psychiatry research, 288, 112972. https:// doi.org/10.1016/j.psychres.2020.112972

Notoatmodjo, S. (2012). Promosi Kesehatan dan Perilaku Kesehatan (R. Cipta (ed.)).

Papagiannis, D., Malli, F., Raptis, D. G., Papathanasiou, I. V., Fradelos, E. C., Daniil, Z., Rachiotis, G., \& Gourgoulianis, K. I. (2020).
Assessment of Knowledge, Attitudes, and Practices Towards New Coronavirus (SARS-CoV-2) of Health Care Professionals In Greece Before The Outbreak Period. International Journal of Environmental Research and Public Health, 17(14), 1-14. https://doi.org/10.3390/ijerph17144925

Peres, D., Monteiro, J., \& Boléo-Tomé, J. (2021). Medical masks' and respirators' pattern of use, adverse effects and errors among Portuguese health care professionals during the COVID-19 pandemic: A cross-sectional study. American Journal of Infection Control. https://doi.org/10.1016/ j.ajic.2021.10.002

Sahiledengle, B., Gebresilassie, A., Getahun, T., \& Hiko, D. (2018). Infection Prevention Practices and Associated Factors among Healthcare Workers in Governmental Healthcare Facilities in Addis Ababa. Ethiopian Journal of Health Sciences, 28(2), 177-186. https://doi.org/10.4314/ ejhs.v28i2.9

Storr, J., Twyman, A., Zingg, W., Damani, N., Kilpatrick, C., Reilly, J., Price, L., Egger, M., Grayson, M. L., Kelley, E., Allegranzi, B., Caluwaerts, A., El-Asady, R., Fisher, D., Gastmeier, P., Holmes, A., Jayatilleke, K., McLaws, M. L., Mehta, G., ... Curiel, E. V. (2017). Core components for effective infection prevention and control programmes: New WHO evidence-based recommendations. Antimicrobial Resistance and Infection Control, 6(1). https://doi.org/10.1186/ s13756-016-0149-9

Waleleng, V., Doda, V. D., \& Manampiring, A. E. (2020). Hubungan antara Promosi Kesehatan dan Keselamatan Kerja (K3) dengan Tindakan Pencegahan Covid-19 pada Pegawai di Salah Satu RS di Provinsi Sulawesi Utara. Sam Ratulangi Journal of Public Health, 1(March), 52-60. http:// dx.doi.org/10.35801/srjoph.v1i2.31987

Zhang, N., Chen, X., Jia, W., Jin, T., Xiao, S., Chen, W., \& Kang, M. (2021). Evidence for lack of transmission by close contact and surface touch in a restaurant outbreak of COVID-19. Journal of Infection. https:// doi.org/10.1016/j.jinf.2021.05.030 